\title{
PENGETAHUAN IBU TENTANG KARIES GIGI ANAK PRASEKOLAH (Studi Pada Anak TK Dharma Wanita Desa Klanderan Kecamatan Plosoklaten Kabupaten Kediri Tahun 2020) \\ Zulfa Risqi Amelia', Imam Sarwo Edi ${ }^{2}$, Sunomo Hadi ${ }^{3}$ \\ ${ }^{123 P o l t e k k e s ~ K e m e n k e s ~ S u r a b a y a, ~ J u r u s a n ~ K e p e r a w a t a n ~ G i g i ~}$ \\ Email : zulfarizqiamelia16@gmail.com ; imamsarwoedi@yahoo.co.id ; sunomohadi@gmail.com
}

\begin{abstract}
The problem in this study is the high number of dental caries in preschool children in Dharma Wanita Kindergarten, Klanderan Village, Plosoklaten Subdistrict, Kediri Regency in 2020. The purpose of this study is to know the mother's knowledge about dental caries in preschool children in Dharma Wanita Kindergarten in Klanderan Village, Plosoklaten District, Kediri Regency in 2020. The method in this research is to fill out the questionnaire sheet. Research data analysis technique is to calculate the average answer based on the score of each answer from the respondent. The total number of answers obtained from respondents, calculated in the form of distribution, frequency and percentage and presented in tabular form. The results of this study are the level of maternal knowledge about dental caries in preschool children by $66 \%$, from the total number of respondents and included in the medium criteria
\end{abstract}

Keyword : Mother's Knowledge, Dental caries, Preschool children

Abstrak: Masalah dalam penelitian ini adalah tingginya angka karies gigi pada anak prasekolah di TK Dharma Wanita Desa Klanderan Kecamatan Plosoklaten Kabupaten Kediri tahun 2020. Tujuan penelitian ini yaitu diketahuinya Pengetahuan ibu tentang karies gigi pada anak prasekolah di TK Dharma Wanita Desa Klanderan Kecamatan Plosoklaten Kabupaten Kediri tahun 2020. Metode dalam penelitian ini yaitu dengan melakukan pengisian lembar kuisoner. Teknik analisa data penelitian adalah menghitung rata-rata jawaban berdasarkan skoring setiap jawaban dari responden. Jumlah seluruh jawaban yang diperoleh dari responden, dihitung dalam bentuk distribusi, frekuensi dan persentasi dan disajikan dalam bentuk tabel. Hasil dari penelitian ini adalah tingkat pengetahuan ibu tentang karies gigi pada anak prasekolah sebesar $66 \%$, dari keseluruhan jumlah responden dan masuk dalam kriteria sedang.

Kata Kunci: Pengetahuan Ibu, Karies Gigi, Anak Prasekolah

Copyright (C) 2020 Jurnal Skala Kesehatan. Politeknik Kesehatan Banjarmasin All rights reserved

Corresponding Author:

Zulfa Risqi Amelia,

Poltekkes Kemenkes Surabaya

Jurusan Keperawatan Gigi

Email : zulfarizqiamelia16@gmail.com 


\section{PENDAHULUAN}

Kesehatan gigi dan mulut merupakan bagian dari kesehatan tubuh yang tidak dapat dipisahkan satu dengan yang lainnya, sebab kesehatan gigi dan mulut akan mempengaruhi kesehatan tubuh. Peranan rongga mulut sangat besar bagi kesehatan dan kesejahteraan manusia. Secara umum, seseorang dikatakan sehat bukan hanya tubuhnya yang sehat melainkan juga sehat rongga mulut dan giginya [1].

Kesehatan gigi dan mulut merupakan salah satu komponen dari kesehatan secara umum dan juga merupakan faktor yang penting dalam pertumbuhan normal dari anak. Masalah kesehatan mulut dapat mempengaruhi perkembangan umum anak-anak, kesehatan tubuh secara umum dan juga dapat berdampak negatif terhadap kualitas hidup karies gigi masih jadi masalah kesehatan anak [2]. Permasalahan karies gigi pada anak usia dini menjadi penting karena karies gigi menjadi indikator keberhasilan upaya pemeliharaan kesehatan gigi anak. Gigi bagi seorang anak adalah hal yang sangat penting dalam proses tumbuh kembang. Fungsi gigi sangat diperlukan dalam masa anak-anak, yaitu sebagai alat pengunyah, penunjang estetika wajah anak dan khusunya gigi sulung berguna sebagai panduan pertumbuhan gigi permanen ${ }^{[3]}$

Berdasarkan hasil utama Riset Kesehatan Dasar (RISKESDAS) $2018^{[4]}$ Kementerian Kesehatan Badan Penelitian dan Pengembangan Kesehatan menunjukkan bahwa 63,7 \% anak usia 5 tahun memiliki angka pengalaman karies gigi (deft) $\geq 6$ (masuk dalam kategori karies anak usia dini yang parah / Severe Early Childhood Caries (S-ECC). Pada Usia 5-6 tahun prevalensi gigi karies masih sangat tinggi yakni 93\%, artinya hanya 7\% anak Indonesia yang bebas dari karies gigi. Dampaknya diperkirakan tingginya gangguan pengunyahan yang berkontribusi pada hambatan asupan Gizi dan gangguan maloklusi gigi.

Prevalensi karies rampan mencapai tingkat yang tinggi diberbagai negara dan keparahannya meningkat seiring pertambahan usia anak. Laporan mengenai kerusakan gigi di Indonesia bahwa kerusakan gigi sulung terutama karies rampan masih jarang dilakukan, walaupun observasi lapangan menunjukkan bahwa cukup banyak dijumpai karies rampan pada anak-anak prasekolah.

Berdasarkan pemeriksaan yang dilakukan oleh peneliti pada anak usia 3-5 tahun di Taman Kanak-Kanak Dharma Wanita di Desa Klanderan Kecamatan Plosoklaten Kabupaten Kediri pada tanggal 09 September 2019 bahwa 30 balita berusia 3-5 tahun yang dilakukan pemeriksaan terdapat 24 balita yang mengalami kerusakan gigi (rampan karies) dan 6 balita yang memiliki gigi sehat. Hasil keseluruhan def-t 5,5.

\section{BAHAN DAN METODE}

Berdasarkan Komisi Etik Poltekkes Kemenkes Surabaya, penelitian ini dinyatakan layak etik untuk dilanjutkan. Jenis penelitian yang digunakan adalah deskriptif. Populasi dalam penelitian ini yakni 30 ibu yang mempunyai anak bersekolah di TK Dharma Wanita. Metode yang digunakan untuk pengumpulan data yaitu metode pengisian lembar kuisoner. Teknik analisis dalam penelitian ini menghitung rata-rata jawaban berdasarkan skoring setiap jawaban dari responden. Jumlah seluruh jawaban yang diperoleh dari responden dihitung dalam bentuk distribusi, frekuensi dan persentasi, dan disajikan dalam bentuk tabel. 


\section{HASIL DAN PEMBAHASAN}

\section{Pengetahuan Ibu Tentang Pengertian Karies Pada Anak Prasekolah Di TK Dharma Wanita Desa Klanderan Kecamatan Plosoklaten Kabupaten Kediri}

Berdasarkan distribusi jawaban responden tentang pengetahuan pengertian karies $(80 \%)$ termasuk dalam kategori baik. Data lengkap disajikan pada tabel berikut.

Tabel. 1 Distribusi Frekuensi Berdasarkan Pengetahuan Ibu Tentang Pengertian Karies Pada Anak Prasekolah di TK Dharma Wanita Klanderan 2020

\begin{tabular}{llcccc} 
& \multicolumn{1}{c}{ Pernyataan } & \multicolumn{3}{c}{ Jawaban Responden } \\
\cline { 3 - 6 } & \multicolumn{2}{c}{ Benar } & \multicolumn{3}{c}{ Salah } \\
\cline { 3 - 6 } & & Frekuensi & $\%$ & Frekuensi & $\%$ \\
\hline 1 & $\begin{array}{l}\text { Apa yang dimaksud dengan } \\
\text { gigi berlubang }\end{array}$ & 26 & $86 \%$ & 5 & $14 \%$ \\
\hline 2 & $\begin{array}{l}\text { Penyebab dari gigi berlubang } \\
\text { adalah }\end{array}$ & 28 & $93 \%$ & 2 & $7 \%$ \\
\hline 3 & $\begin{array}{l}\text { Jenis makanan yang baik } \\
\text { untuk gigi adalah }\end{array}$ & 24 & $80 \%$ & 6 & $20 \%$ \\
\hline 4 & $\begin{array}{l}\text { Makanan yang dapat } \\
\text { merusak gigi }\end{array}$ & 18 & $60 \%$ & 12 & $40 \%$ \\
\hline$\quad$ Jumlah & 96 & $319 \%$ & 25 & $81 \%$ \\
\hline Rata-rata & 24 & $80 \%$ & 6,25 & $20 \%$ \\
\hline
\end{tabular}

Berdasarkan hasil analisis data distribusi jawaban responden tentang pengetahuan pengertian karies gigi termasuk dalam kategori baik adalah faktor lingkungan tempat tinggal yang mudah mendapatkan informasi dari berbagai hal. Hasil penelitian [5] menyatakan bahwa tingkat pengetahuan ibu tentang karies gigi menunjukkan rata-rata dalam kategori baik. Salah satu faktor yang mempengaruhi tingkat pengetahuan ibu tentang karies gigi adalah lingkungan tempat tinggal yang memudahkan mendapatkan informasi tentang kesehatan gigi dan mulut khususnya karies gigi lewat media massa, penyuluhan dari petugas kesehatan, dan iklan-iklan, secara tidak sadar hal tersebut dapat meningkatkan pengetahuan ibu tentang kesehatan gigi dan mulut khususnya karies gigi.

Pengetahuan merupakan hasil dari tahu, dan ini terjadi setelah orang melakukan penginderaan terhadap suatu objek tertentu. Penginderaan terjadi melalui pancaindra manusia, yakni indra penglihatan, pendengaran, penciuman, rasa dan raba. Sebagian besar pengetahuan bisa diperolah melalui mata dan telinga. Faktor yang mempengaruhi dalam pengetahuan adalah Pendidikan, informasi, pekerjaan, social ekonomi, minat, pengalaman, dan usia [6]

Karies seringkali belum dijadikan prioritas oleh orangtua dalam menjaga kesehatan gigi anak, salah satu studi yang dilakukan oleh Puspitoningsih (2012) [7] di TK Dharma Wanita Kecamatan Kemusu Boyolali menunjukkan sebanyak $64 \%$ anak mengalami karies gigi. Para ibu menganggap karies bukan masalah yang serius bagi kesehatan gigi anak, ibu tidak pernah memeriksakan kesehatan gigi anak ke puskesmas atau klinik gigi, dan anak tidak diajarkan untuk menggosok gigi 2 kai sehari.

Dapat disimpulkan hasil penelitian pengetahuan ibu tentang pengertian karies gigi anak prasekolah TK Dharma Wanita Klanderan dalam kategori baik, akan tetapi angka karies gigi pada anak tinggi karena adanya penyuluhan atau informasi dari guru, petugas kesehatan dan media 
massa di sekolah sehingga para ibu tahu dan memahami karies gigi. Karies gigi pada anak TK Dharma Wanita Klanderan Plosoklaten Kediri masih tinggi disebabkan masih begitu banyak faktor penyebab karies yang belum menjadi perhatian penting khususnya pada faktor makan yang dikonsumsi oleh anak baik di rumah maupun disekolah. Hal inilah yang menjadi salah satu perhatian mengapa angka karies tinggi tetapi pengetahuan ibu mengenai pengertian karies baik

2 Pengetahuan Ibu Tentang Cara Pemeliharaan Kesehatan Gigi Dan Mulut Pada Anak Prasekolah Di TK Dharma Wanita Desa Klanderan Kecamatan Plosoklaten Kabupaten Kediri

Berdasarkan distribusi jawaban responden tentang pengetahuan cara pemeliharaan kesehatan gigi dan mulut sebesar (43\%) termasuk dalam kategori kurang. Data lengkap disajikan pada tabel berikut.

\begin{tabular}{|c|c|c|c|c|c|}
\hline \multirow{3}{*}{ No } & \multirow{3}{*}{ Pernyataan } & \multicolumn{4}{|c|}{ Jawaban Responden } \\
\hline & & \multicolumn{2}{|c|}{ Benar } & \multicolumn{2}{|c|}{ Salah } \\
\hline & & Frekuensi & $\%$ & Frekuensi & $\%$ \\
\hline 1 & $\begin{array}{l}\text { Waktu yang tepat untuk } \\
\text { menyikat gigi }\end{array}$ & 11 & $37 \%$ & 19 & $63 \%$ \\
\hline 2 & $\begin{array}{l}\text { Minimal berapa kali } \\
\text { menyikat gigi }\end{array}$ & 14 & $47 \%$ & 16 & $53 \%$ \\
\hline 3 & $\begin{array}{l}\text { Cara memilih sikat gigi } \\
\text { untuk anak adalah }\end{array}$ & 13 & $43 \%$ & 17 & $57 \%$ \\
\hline 4 & $\begin{array}{l}\text { Sebaiknya kapan sikat gigi } \\
\text { anak diganti }\end{array}$ & 17 & $57 \%$ & 13 & $43 \%$ \\
\hline 5 & $\begin{array}{l}\text { Apakah sikat gigi boleh } \\
\text { dipakai bersama-sama }\end{array}$ & 26 & $87 \%$ & 4 & $13 \%$ \\
\hline 6 & $\begin{array}{l}\text { Cara membersihkan sikat } \\
\text { gigi setelah dipakai adalah }\end{array}$ & 14 & $47 \%$ & 16 & $53 \%$ \\
\hline 7 & $\begin{array}{l}\text { Kapan sebaiknya ibu } \\
\text { memeriksakan gigi anak }\end{array}$ & 9 & $30 \%$ & 21 & $70 \%$ \\
\hline 8 & $\begin{array}{l}\text { Bagaimana penggunaan } \\
\text { pasta gigi pada anak usia } 3 \\
-5 \text { tahun }\end{array}$ & 7 & $23 \%$ & 23 & $73 \%$ \\
\hline 9 & $\begin{array}{l}\text { Bagaimana cara } \\
\text { menggosok gigi bagian } \\
\text { depan yang menghadap ke } \\
\text { bibir }\end{array}$ & 4 & $13 \%$ & 26 & $87 \%$ \\
\hline 10 & $\begin{array}{l}\text { Bagaimana cara } \\
\text { menggosok gigi bagian } \\
\text { dalam depan }\end{array}$ & 5 & $17 \%$ & 25 & $83 \%$ \\
\hline 11 & $\begin{array}{l}\text { Bagaimana cara } \\
\text { menggosok gigi bagian } \\
\text { untuk mengunyah }\end{array}$ & 29 & $97 \%$ & 1 & $3 \%$ \\
\hline
\end{tabular}




\begin{tabular}{|c|c|c|c|c|c|}
\hline 12 & $\begin{array}{l}\text { Bagaimana cara } \\
\text { menggosok gigi bagian } \\
\text { yang menghadap ke pipi }\end{array}$ & 2 & $7 \%$ & 28 & $93 \%$ \\
\hline 13 & $\begin{array}{l}\text { Bagaimana cara } \\
\text { menggosok gigi bagian } \\
\text { yang menghadap lidah }\end{array}$ & 7 & $23 \%$ & 23 & $73 \%$ \\
\hline 14 & $\begin{array}{l}\text { Jika anak jajan diluar, apa } \\
\text { yang bisa dilakukan untuk } \\
\text { membersihkan gigi }\end{array}$ & 26 & $87 \%$ & 4 & $13 \%$ \\
\hline & Jumlah & 184 & $613 \%$ & 236 & $786 \%$ \\
\hline & Rata-rata & 13 & $43 \%$ & 17 & $57 \%$ \\
\hline
\end{tabular}

Berdasarkan hasil analisis data distribusi jawaban responden tentang pengetahuan cara pemeliharaan kesehatan gigi dan mulut termasuk dalam kategori kurang, karena sikap ibu yang kurang memperhatikan cara pemeliharaan kesehatan gigi anak khusunya pada cara menggosok gigi. Sikap merupakan reaksi atau respons yang masih tertutup dari seseorang terhadap suatu stimulus atau objek. Manifestasi sikap itu tidak dapat langsung dilihat, tetapi dapat ditafsirkan terlebih dahulu dari perilaku yang tertutup. Sikap itui merupakan reaksi tertutup, bukan merupakan reaksi terbuka. [8]

Hasil penelitian ini sesuai dengan penelitian Yohannes (2016) [9] Bahwa Pemeliharaan kesehatan gigi dan mulut yang tidak diperhatikan dengan baik dipengaruhi oleh pengetahuan kesehatan gigi dan mulut yang kurang. Kebiasaan-kebiasaan ibu yang kurang baik terhadap pengimplementasian pemiliharaan kesehatan gigi anak. Implementasi dibutuhkan karena anak usia taman kanak-kanak belum mampu mengurus dirinya sendiri. Selain itu, para ibu menganggap karies gigi bukanlah masalah yang serius bagi kesehatan gigi anak

Pemeliharaan kesehatan gigi dan mulut dapat dilakukan dengan cara gigi disikat setidaktidaknya 2 menit supaya air ludah juga dapat keluar dan membersihakan kantong gusi yang terletak diperbatasan gigi dan gusi. Kantong gusi ini mempunyai kedalaman normal 2 - $4 \mathrm{~mm}$ yang perlu dibersihkan untuk mencegah makanan terselip di antaranya. Kemiringan bulu sikat gigi sebesar $45^{\circ}$ pada daerah kantong gusi dapat membantu bulu sikat gigi masuk kedalam kantong gusi untuk pembersihan yang lebih maksimal. [10]

Dapat disimpulkan hasil penelitian pengetahuan ibu tentang cara pemeliharaan kesehatan gigi dan mulut dalam kategori kurang adalah karena kebiasaan-kebiasaan menyikat gigi yang dilakukan sampai saat ini masih belum benar, minimnya kesadaran dan perilaku yang berhubungan dengan kesehatan gigi, minimnya kesadaran masyarakat untuk memeriksakan gigi ke dokter gigi secara teratur.

\section{Pengetahuan Tentang Akibat Tidak Memelihara Kesehatan Gigi Dan Mulut Pada Anak Prasekolah Di TK Dharma Wanita Desa Klanderan Kecamatan Plosoklaten Kabupaten Kediri.}

Berdasarkan distribusi jawaban responden tentang akibat tidak memelihara kesehatan gigi dan mulut sebesar (75\%) termasuk dalam kategori cukup. Data lengkap disajikan pada tabel berikut. 
Jawaban Responden

\begin{tabular}{clcccc}
\multirow{2}{*}{ No } & Pernyataan & \multicolumn{2}{c}{ Benar } & \multicolumn{2}{c}{ Salah } \\
\cline { 3 - 6 } & Frekuensi & $\%$ & Frekuensi & $\%$ \\
\hline 1 & Akibat malas menggosok gigi & 23 & $77 \%$ & 7 & $23 \%$ \\
\hline 2 & $\begin{array}{l}\text { Akibat dari gigi berlubang } \\
\text { yang tidak dilakukan } \\
\text { perawatan }\end{array}$ & 22 & $73 \%$ & 8 & $27 \%$ \\
\hline Jumlah & 45 & 150 & 15 & $50 \%$ \\
\hline Rata-rata & 22,5 & $75 \%$ & 7,5 & $25 \%$
\end{tabular}

Berdasarkan asil analisis data distribusi jawaban responden tentang akibat tidak memelihara kesehatan gigi dan mulut termasuk dalam kategori cukup, sebagian ibu tidak mengetahui akibat dari tidak memelihara kesehatan gigi dan mulut anak yang dapat berakibat ada tumbuh kembang anak. Dampak yang ditimbulkan dari hal ini yang dialami anak-anak akan menghambat pada kualitas anak tersebut.Menurut Sariningsih [11] akibat klinis yang ditimbulkan oleh karies gigi pada mulanya tampak sebagai bercak keputihan (white spot) pada email, yang melebar mengelilingi pada daerah leher gigi (perbatasan anatara gigi dan gusi) dengan cepatnya karies gigi, terutama yang telah melibatkan pupla, akan mengakibatkan rasa sakit dan infeksi, selanjutnya akan berakibat pada kesehatan umum karena anak tidak dapat makan dan tidur dengan lelap. Selain itu akibat dari karies adalah rasa sakit, kesulitan mengunyah, menimbulkan infeksi, menimbulkan bau mulut.

\section{Rekapitulasi Hasil Pengetahuan Ibu Tentang Karies Gigi Pada Anak Prasekolah (Studi Pada Anak Tk Dharma Wanita Desa Klanderan Kecamatan Plosoklaten Kabupaten Kediri Tahun 2020)}

Rekapitulasi hasil pengetahuan ibu tentang karies gigi pada anak prasekolah (studi pada anak Tk Dharma Wanita Desa Klanderan Kecamatan Plosoklaten Kabupaten Kediri tahun 2020)

\begin{tabular}{cccc}
\multirow{2}{*}{ No } & Pernyataan & \multicolumn{2}{c}{ Jawaban Responden (\%) } \\
\cline { 3 - 4 } & & Benar & Salah \\
\hline 1 & Pengetahuan ibu tentang pengertian karies & $80 \%$ & $20 \%$ \\
\hline 2 & $\begin{array}{l}\text { Pengetahuan ibu tentang cara } \\
\text { pemeliharaan kesehatan gigi dan mulut }\end{array}$ & $43 \%$ & $57 \%$ \\
\hline 3 & $\begin{array}{l}\text { Pengetahuan tentang akibat tidak } \\
\text { memelihara kesehatan gigi dan mulut }\end{array}$ & $75 \%$ & $25 \%$ \\
\hline & Jumlah & $198 \%$ & $104 \%$ \\
\hline & Rata-rata & $66 \%$ & $35 \%$
\end{tabular}


Dapat diketahui bahwa pengetahuan ibu tentang karies gigi pada anak prasekolah sebesar $66 \%$ termasuk dalam kategori sedang. Nilai tersebut diperoleh berdasarkan perhitungan rata-rata jawban benar, yang meliputi 3 aspek yaitu pengetahuan tentang pengertian karies gigi, pengetahuan tentang cara pemeliharaan kesehatan gigi dan mulut, pengetahuan tentang akibat tidak memelihara kesehatan gigi dan mulut.

\section{KESIMPULAN}

Berdasarkan hasil penelitian tentang "Pengetahuan Ibu Tentang Karies Gigi Pada Anak Prasekolah TK Dharma Wanita Desa Klanderan Kecamatan Plosoklaten Kediri dapat disimpulkan masuk dalam kategori sedang dengan perolehan nilai $66 \%$.

\section{UCAPAN TERIMAKASIH}

Kepada Ketua Jurusan Keperawatan Gigi Poltekkes Kemenkes Surabaya yang telah memberikan kesempatan untuk melakukan penelitian, serta dosen pembimbing yang telah senantiasa membimbing peneliti dan tak lupa Kepala TK Dharma Wanita Klanderan serta para ibu yang telah berkenan dan mengizinkan peneliti untuk melaksanakan penelitian.

\section{DAFTAR PUSTAKA}

[1] M. Gultom, "Pengetahuan, Sikap, dan Tindakan Ibu-lbu Rumah Tangga Terhadap Pemeliharaan Kesehatan Gigi dan Mulut Balita Di Kecamatan Balige Kabupaten Toba Samosir," 2009.

[2] S. U. Winda, G. Paulina and A. W. Dinar, "Gambaran Karies Rampan Pada Siswa Pendidikan Anak Usia Dini Di Desa Pineleng II Indah," Jurnal e-Gigi, vol. 3 Nomor 1, 2015.

[3] T. Y. Worang, D. H. C. Pangemanan and D. A. Wicaksono, "Hubungan Tingkat Pengetahuan Orangtua Dengan Kebersihan Gigi dan Mulut Anak TK Tunas Bhakti Manado, " Jurnal e-Gigi, vol. 2 nomor 2, 2014.

[4] Kemenkes RI, "Riset Kesehatan Dasar Nasional," Laporan Depkes RI, Jakarta, 2018.

[5] C. D. Jayanti, "Hubungan Tingkat Pengetahuan Ibu Tentang Karies Gigi Dengan Kejadian Karies Gigi Pada Anak TK Aisyiyah Kateguhanan Sawit Boyolali," Universitas Muhammadiyah Surakarta, Surakarta, 2012.

[6] S. Notoatmodjo, Promosi Kesehatan dan Perilaku Kesehatan, Jakarta: Rineka Cipta, 2012.

[7] N. Puspitoningsih, W. Safitri and A. Istianingtyas, "Persepsi Ibu Tentang Karies Gigi Pada Anak Prsekolah di TK Dharma wanita Kecamatan Kemusu Boyolali Surakarta," Program Studi Keperawatan Stikes Kusuma Husada, Surakarta, 2012.

[8] S. Notoatmodjo, Promosi Kesehatan dan Perilaku Kesehatan, Jakarta: Rineka Cipta, 2012.

[9] I. G. Yohannes, "Hubungan Pengetahuan Kebersihan Gigi dan Mulut dengan Status Kebersihan Pada SIswa SMAN 9 Manado," Jurnal Universitas Sam Ratulangi, 2016.

[10] C. Maulani, Panduan Orangtua dalam Merawat dan Menjaga Kesehatan Gigi bagi Anak-Anaknya, Jakarta: PT Elex Media Komputindo, 2005.

[11] Sariningsih, Teori dan Pencegahan Karies Gigi Pada Anak, Yogyakarta: Nuha Medika, 2014. 